\title{
MAIZE GROWTH AND YIELD RESPONSE TO INCREMENTAL RATES OF PHOSPHORUS IN P-DEPLETED LIXISOLS OF NOTHERN GHANA
}

\author{
* Ebenezer Ayew Appiah, Joseph Xorse Kugbe and Ahmed Mahama Rufai \\ University for development studies, Faculty of Agriculture, Department of Agronomy
}

https://doi.org/10.35410/IJAEB.2021.5643

\begin{abstract}
It has long been postulated that the efficient use of phosphatic fertilizers must be based on information on inherent soil P-levels for the development of site-specific fertilization that must, in turn, be based on crop response to known nutrient levels. However knowledge remains relatively sparse on crop response to incremental rates of $\mathrm{P} 2 \mathrm{O} 5$ fertilization on soils of known $\mathrm{P}$ levels to serve as proxy for development of site-specific P2O5 predicting tool that is required for optimum maize production. In the P-deficient Lixisols of northern Ghana, the effect of eleven rates of $\mathrm{P} 2 \mathrm{O} 5$ fertilization were evaluated for growth and yield of maize. The P2O5 rates used were $00,05,10,15,20,25,30,35,40,45$, and $50 \mathrm{~kg} / \mathrm{ha}$; laid out in a Randomized Complete Block Design with four replicates. Data were collected on maize growth and yield and subjected to analyses of variance, where means were separated at a probability of $5 \%$ using the least significant difference. Results of the evaluation indicated significant effect of P2O5 rate on maize plant height, leaf area index, days to 50\% flowering, cob weight, cob length, 100 seed weight, straw weight and grain yield. Increasing P2O5 rates had pronounced effect on growth, on grain yield and on yield components of maize. Application of $50 \mathrm{~kg} / \mathrm{ha}$ resulted in maximum leaf area index (3.84), 100 seed weight (23.49 g), straw weight $(9.3 \mathrm{t} / \mathrm{ha})$ and grain yield (3.09 t/ha) as compared to the minimum values in the control treatments $(1.57,14.8 \mathrm{~g}, 3.3 \mathrm{t} / \mathrm{ha}$ and $0.71 \mathrm{t} / \mathrm{ha}$ respectively). The findings show that phosphorus fertilization is essential for maize growth and yield and serves as an entry point for relating soil test data with corresponding yield and the subsequent development of a fertilization tool that can help to predict site-specific P2O5 fertilization, based on soil test results.
\end{abstract}

Keywords: Maize growth, yield and yield components, phosphorus fertilization, site-specificity, crop nutrition.

\section{INTRODUCTION}

Maize is a versatile cereal crop that is cultivated under wide agro-ecological environments $[1,2]$. The use of maize crop has replaced that of most indigenous cereal crops such us sorghum and millet in Ghana [3]. Maize remains a significant crop for the agricultural sector and for ensuring food security [4], being the prime source of feed for the livestock sub-sector [5]. The versatile environment under which the crop grows has made it possible to cultivate it under the diverse agro climatic conditions of Ghana: ranging from the coastal, savannah, transition, and the forest zones. For these reasons, most household livelihoods in the rural areas are dependent on the yield 
of the crop. The average yield of maize, however, remains relatively low (about $1.7 \mathrm{t} / \mathrm{ha}$ ) compared to an expected yield of around $6 \mathrm{t} / \mathrm{ha}[6,7,8]$.

Phosphorus (P) is the second most limiting nutrient in most cropping systems of Africa [9, 10]. The nutrient is required for most physiological and morphological functions of crops [11]. During maize growth, phosphorus is required for root and grain development [12]. It is also required for numerous biochemical processes and for the metabolism of carbohydrates, fats and proteins. Phosphorus is also required for the breakdown of carbohydrates to release energy for use by the plant 13]. According to [14] phosphorus is involved in leaf development and senescence in maize which in turn has profound effect on leaf area, light interception, photosynthesis and assimilate accumulation. Due to the numerous physiological and morphological functions of $\mathrm{P}$ in maize growth and development, knowledge on $\mathrm{P}$ nutrition has been used to improve yield in most nutrient-poor soils [15].

In most resource-poor rural communities of Ghana, maize farmers continue to depend on inherent soil fertility for maize production. The naturally low nutrient status on the other hand render such soils unsuitable for maize production [16], which necessitate application of external nutrients to meet the crop's nutrient demand [17]. In cases where external $\mathrm{P}$ fertilizers are applied, crop performances have been noted to improve with successive fertilization. In some cases, residual P has been noted to increase yield of successive maize crops [18]. In a study by [19], they noted that the application of a mixture of urea, triple superphosphate (TSP) fertilizer and farmyard manure improved the crop use of $\mathrm{N}$ and $\mathrm{P}_{2} \mathrm{O}_{5}$ fertilizer.

As $\mathrm{P}_{2} \mathrm{O}_{5}$ remains an important and irreplaceable fertilizer for maize production, the source of the nutrient is reported to be limited and depleting at an alarming rate [20]. [21] Reported that the global stock pile of phosphatic minerals used for the synthesis of $\mathrm{P}_{2} \mathrm{O}_{5}$ fertilizers will be depleted in the next decade. This notwithstanding, excessive use of $P$ fertilizers have been noted to cause eutrophication and other environmentally alarming phenomena [22]. To reduce pollution and also help to extend the shelf life of natural $\mathrm{P}$ deposits for sustainable and continuous production of food, mankind is required to make judicious use of $\mathrm{P}$ fertilizers.

P uptake varies by crop type and level of soil-P [23]. Therefore, crop and site-specific fertilization that are based on individual crop's need has been propounded as the most resilient and environmentally sustaining approach to $P$ fertilization. The development of such site-specific nutrient prediction tools, however, requires three tire levels of studies and data collection: knowledge on crop response to known soil fertility status as base for tool development, development and evaluation of the performance of the given predicting tool, and then validation of the performance of the developed tool [24, 25].

Across the Lixisols of the northern savannah Agro-ecological zone where the bulk of corn is grown, limited data exist on crop responses to known soil phosphorus levels to serve as the first step in the development of any phosphorus-predicting tools for maize production. This lack in knowledge hinders efforts that are aimed at developing site-specific fertilization regimes; and has largely informed a one-suite recommended rate of $45 \mathrm{~kg} / \mathrm{ha}$ of $\mathrm{P}_{2} \mathrm{O}_{5}$ for all maize growing sites 
Vol. 06, No. 03; 2021

ISSN: $2456-8643$

irrespective of the inherent differences and variations in soil phosphorus levels at different locations [24]. Therefore, this study was carried out to assess the response of maize growth, yield and yield components to known levels of $\mathrm{P}_{2} \mathrm{O}_{5}$ to serve as an entry point for subsequent development of a phosphorus predicting-tool for site-specific $\mathrm{P}_{2} \mathrm{O}_{5}$ fertilization.

\section{MATERIALS AND METHODS}

\subsection{Experimental site}

The study was carried out under greenhouse conditions as a pot experiment. The experimental site is located on latitude $09^{\circ} 24^{\prime} 44.4 " \mathrm{~N}$ and longitude $00^{\circ} 58^{\prime} 49.7 " \mathrm{~W}$. The area falls under savannah agro ecology with guinea savanna characteristics [26]. The area experiences a unimodal rainfall pattern, with an annual mean rainfall of 1000 to $1022 \mathrm{~mm}$ [24].

Mean monthly temperature ranges from minimum of $21.9^{\circ} \mathrm{C}$ and maximum of $34.1^{\circ} \mathrm{C}$. Relative humidity ranges from a minimum of $46 \%$ to maximum of $76.8 \%$. The soils were developed from ferruginized ironstone and gravels [27]. The soils were sandy loam in texture and moderately drained. They developed from Voltaian sandstone and classified as flaplic lixisol that are locally called the Nyankpala series [28].

\subsection{Experimental design and treatment}

A single factor experiment, consisting of inorganic $\mathrm{P}_{2} \mathrm{O}_{5}$ rates as treatment was used in the study. Eleven levels of $\mathrm{P}_{2} \mathrm{O}_{5}$ rates were used. These were $00,05,10,15,20,25,30,35,40,45$, and 50 $\mathrm{kg} / \mathrm{ha}$ (Table 1). The experiment was laid out in a Randomized Complete Block Design to reduce errors that may be associated with heterogeneity of conditions within the glasshouse. The experiment was replicated four (4) times for each treatment. There were forty-four (44) experimental pots in totality. Nitrogen $(\mathrm{N})$ and $\mathrm{K}_{2} \mathrm{O}$ fertilizers were each applied at optimum rates of 120 and $60 \mathrm{~kg} / \mathrm{ha}$ respectively. These optimum rates of the other primary nutrients were used so that observed differences in growth and yield parameters could be attributed solely to differences in $\mathrm{P}_{2} \mathrm{O}_{5}$ treatments.

Table 1: Rates of $\mathrm{P}_{2} \mathrm{O}_{5}$ used to study the response of maize growth and yield to incremental levels of $\mathrm{P}_{2} \mathrm{O}_{5}$ fertilization. ${ }^{* *} \mathrm{P}_{2} \mathrm{O}_{5}$ rates applied to the pot experiment to calibrate soil test results for $\mathrm{P}_{2} \mathrm{O}_{5}$ fertilization.

\begin{tabular}{|c|c|c|c|c|}
\hline Treatment & $\begin{array}{l}\mathrm{P}_{2} \mathrm{O}_{5} \\
\text { calibration } \\
\text { rate }(\mathrm{kg} / \mathrm{ha})\end{array}$ & $\begin{array}{l}* * \mathrm{P}_{2} \mathrm{O}_{5} \text { rate } \\
\text { applied in pot } \\
\text { experiment } \\
(\mathrm{kg} / \mathrm{ha})\end{array}$ & $\begin{array}{l}\text { Mass of } \mathrm{P}_{2} \mathrm{O}_{5} \\
(\mathrm{~g} / \mathrm{kg} \text { soil })\end{array}$ & $\begin{array}{l}* * \text { Mass of } \mathrm{P}_{2} \mathrm{O}_{5} \text { used }(\mathrm{g} \\
\left.\mathrm{P}_{2} \mathrm{O}_{5} / \mathrm{kg} \text { soil }\right)\end{array}$ \\
\hline 1 & 0 & 0 & 0.000 & 0.000 \\
\hline 2 & 5 & 15 & 0.057 & 0.171 \\
\hline 3 & 10 & 30 & 0.115 & 0.345 \\
\hline
\end{tabular}




\begin{tabular}{|lllll|}
\hline 4 & 15 & 45 & 0.173 & 0.519 \\
5 & 20 & 60 & 0.231 & 0.693 \\
6 & 25 & 75 & 0.288 & 0.864 \\
7 & 30 & 90 & 0.346 & 1.038 \\
8 & 35 & 105 & 0.404 & 1.212 \\
9 & 40 & 120 & 0.461 & 1.383 \\
10 & 45 & 135 & 0.519 & 1.557 \\
11 & 50 & 150 & 0.577 & 1.731 \\
\hline
\end{tabular}

**Estimated root zone certainty between rhizosphere-applied rate and rate due to continues mass of soil $=$ three times the actual rate applied on a farmer's field.

The estimated root zone certainty between rhizoshpere applied rate and rate due to continuous mass of soil (Table 1) was done by multiplying the actual rate by a factor of three. The factor of three represents an estimate of ratio of root zone surface area to total surface area between any two stands. This estimated root zone certainty was essential in the pot experiment because, in the normal farmers' fields, any rate to be added per unit area are point applied within the root's rhizosphere and not randomly spread over the entire surface area. So that at any time, soils picked within the inter and intra rows on a farmer's field would normally have lower nutrient concentrations than soils that would have been picked at the point where the fertilizers were applied. To ensure uniform concentration of nutrients at any sampled points of soils for the pot experiment, this proxi of nutrient content was essential. The estimated final rate of nutrient applied (Table 1) was then mixed thoroughly with the $10 \mathrm{~kg}$ soil to have a uniform nutrient concentration within the potted soil. In this case when soil samples are taken from the pot for analysis, the nutrient concentration will not differ from one point to another.

\subsection{Soil sampling}

Prior to planting, soil samples were collected from the experimental soil at depth of $0-20 \mathrm{~cm}$. The collected soil samples were air-dried and passed through $2 \mathrm{~mm}$ sieve to remove large particles, debris and stones that were larger than $2 \mathrm{~mm}$. Soil physico chemical parameters were then analyzed prior to fertilizer treatment. Soil $\mathrm{pH}$ was determined by using the electrometric method in a soil: water ratio of 1:2.5. Organic carbon was determined by the Wakley and Black procedure [29]. Total nitrogen was determined by the micro Kjeldahl method [30], while Bray 1 extraction solution procedure [31] was used for determination of available P. Textural analysis was done by using the hydrometer method.

Sieved soil samples were then mixed thoroughly with the given treatment rate of $\mathrm{P}_{2} \mathrm{O}_{5}$ (Table 1) and potted at rate of $10 \mathrm{~kg}$ soil/pot. 


\subsection{Agronomic practices}

Hand-watering of the potted soils was done twice daily, in the morning and late afternoon, to enhance soil moisture availability to the plant and also to facilitate germination, and growth of the maize plants. Three (3) maize seeds were planted at stake. The maize plants were thinnedout, two weeks after planting to one plant per pot and all weeds that appeared in the pots were removed immediately by hand to prevent competition with the maize plants.

Nitrogen and potassium as $\mathrm{N}$ and $\mathrm{K}_{2} \mathrm{O}$ were respectively applied as side placements. Nitrogen was applied in two splits. The first application was done 10 days after emergence, together with the $\mathrm{K}_{2} \mathrm{O}$ at rates of $60 \mathrm{~kg} / \mathrm{ha}$ each. The second application of $\mathrm{N}$ was done 20 days after the first application at an $\mathrm{N}$ rate of $60 \mathrm{~kg} / \mathrm{ha}$. Urea was used as the source of $\mathrm{N}$. Muriate of potash $(\mathrm{KCl})$ was used as the source of $\mathrm{K}_{2} \mathrm{O}(60 \%)$, while triple super phosphate (TSP) $\mathrm{Ca}\left(\mathrm{H}_{2} \mathrm{PO}_{4}\right)$ was used as source of the $\mathrm{P}_{2} \mathrm{O}_{5}(45 \%)$.

\subsection{Data collection}

Data were collected on the following: initial nutrient levels before fertilization, plant height, leaf area index, days to flowering, straw weight, cob weight, cob length, cob weight, 100 seed weight, and grain yield.

\subsubsection{Plant height}

The height of the maize plants in each pot was measured at 3,6 and 9 weeks after planting (WAP). Tape measure was used to measure the heights from the base of the plant to the longest tip and their averages recorded.

\subsubsection{Leaf area index (LAI)}

Leaf area index was taken at 6 and 9 weeks after planting by measuring the length and the width of the leaves. $\mathrm{LAI}$ was computed by formula, $\mathrm{L} \times \mathrm{W} \times \mathrm{A}$, where: $\mathrm{L}=$ leaf length, $\mathrm{W}=$ leaf width and $\mathrm{A}=\mathrm{a}$ factor of 0.75 for maize crop as described by [32].

\subsubsection{Days to flowering}

The number of days to tasselling was determined as the number of days between when the crop was planted and when it tasseled.

\subsubsection{Cob length}

The cobs from each treatment were selected and their length measured and their averages were recorded. A pair of callipers and a rule was used to measure the cob length.

\subsubsection{Cob weight}

The cobs were selected from each treatment and weighed and their averages recorded. An electronic scale was used to determine the cob weight at harvest. 


\subsubsection{Weight of hundred seeds}

100 maize seeds from each pot were counted and weighed using an electronic scale.

\subsubsection{Straw weight}

The straws of harvested pots were weighed after harvesting and recorded. The harvested straw weights were converted into tons/ha (t/ha) using the equation used by [24, 33] below.

Straw weight $(\mathrm{t} / \mathrm{ha})=\frac{\text { Straw wright }(\mathrm{kg} \text { g pot }) \times \text { Plant density }}{1000}$

Where plant population density $=$ number of plant stands in $10,000 \mathrm{~m}^{2}$ when planted at spacing of $80 \mathrm{~cm} \times 25 \mathrm{~cm}$ (interspacing arrangement for the pot experiment), at one seed per stand. Hence, 1 ha $\left(10,000 \mathrm{~m}^{2}\right)$ area has plant density of 50,000 with same spacing.

\subsubsection{Grain yield}

The grains obtained from pots were threshed, cleaned, dried and weighed in gram for each pot. Total weight of all the grains of a particular pot gives the grain yield in gram per pot and were finally converted into tons/hectare (t/ha), using the equation 2 below, used by [24, 33].

$$
\text { Grain yield }(\mathrm{t} / \mathrm{ha})=\frac{\text { Grain yield per pot } \left.\frac{\mathrm{kg} g}{\text { por }}\right) \times \text { Plant density }}{1000}
$$

Where plant population density $=$ number of plant stands in $10,000 \mathrm{~m}^{2}$ when planted at spacing of $80 \mathrm{~cm} \times 25 \mathrm{~cm}$ (interspacing arrangement for the pot experiment), at one seed per stand. Hence, 1 ha $\left(10,000 \mathrm{~m}^{2}\right)$ area has plant density of 50,000 with same spacing.

\subsection{Data analyses}

Data collected from the pot experiments were subjected to analysis of variance (Anova) to compare crop growth and yield responses between the treatment levels using Genstat $18^{\text {th }}$ edition. Treatment means were separated at a 5\% probability level using the least significant difference.

\section{RESULTS}

The physico-chemical properties of the soil prior to planting are shown in Table 2. The soil was loamy sand in texture. The soil had a $\mathrm{pH}$ of 5.85 which was moderately acidic. The soil's available $\mathrm{P}$ was low and the exchangeable cations $(\mathrm{K}, \mathrm{Ca}$ and $\mathrm{Mg}$ ) were not also high. The total nitrogen and percentage organic carbon were also low.

Table 2: Initial soil physico chemical properties

\begin{tabular}{|llllcllllll|}
\hline $\mathrm{BD}$ & $\mathrm{pH}$ & $\mathrm{O} . \mathrm{C}$ & $\mathrm{N}$ & $\mathrm{P}$ & $\mathrm{K}$ & $\mathrm{Ca}$ & $\mathrm{Mg}$ & SAND & SILT & CLAY \\
$\mathrm{g} / \mathrm{cm}^{3}$ & $\mathrm{H}_{2} \mathrm{O}$ & $\%$ & $\mathrm{mg} / \mathrm{kg}$ & $\mathrm{mg} / \mathrm{kg}$ & $\mathrm{mg} / \mathrm{kg}$ & $\mathrm{Cmol}+\mathrm{kg}$ & $\mathrm{Cmol}+\mathrm{kg}$ & $\%$ & $\%$ & $\%$ \\
& $(1: 2.5)$ & & & & & & & & & \\
& & & & & & & & &
\end{tabular}


Vol. 06, No. 03; 2021

ISSN: $2456-8643$

\begin{tabular}{|lllllllllll|}
\hline \multicolumn{10}{|c|}{$\mid$} & \\
\hline 1.40 & 5.85 & 1.055 & 0.101 & 7.457 & 65.0 & 1.8 & 0.72 & 77.44 & 21.4 & 1.16 \\
\pm 0.254 & \pm 0.295 & \pm 0.041 & \pm 0.308 & \pm 0.403 & \pm 2.677 & \pm 0.285 & \pm 0.097 & \pm 9.395 & \pm 0.985 & \pm 0.047 \\
& & & & & & & & & & \\
\hline
\end{tabular}

* Moisture content on air dry weight basis, $\mathrm{BD}=$ Bulk density, $\mathrm{OC}=$ Organic carbon, $\mathrm{N}=$ Nitrogen, $\mathrm{P}=$ phosphorus, $\mathrm{K}=$ Potassium, $\mathrm{Ca}=\mathrm{Calcium}$, and $\mathrm{Mg}=$ Magnesium

\section{Plant height}

The application of different rates of phosphorus significantly $(P=0.049)$ influenced plant height during the third week after planting. Plant height increased as the $\mathrm{P}_{2} \mathrm{O}_{5}$ rates increased (Figure 1). Application of $\mathrm{P}_{2} \mathrm{O}_{5}$ at rate of $50 \mathrm{~kg} / \mathrm{ha}$ recorded the highest height followed by application at rate of $45 \mathrm{~kg} / \mathrm{ha}$. $\mathrm{P}_{2} \mathrm{O}_{5}$ application at rate of $00 \mathrm{~kg} / \mathrm{ha}$ recorded the least height (Figure 1). Different rates of phosphorus applied had significant $(P=0.001)$ effect on plant height at sixth week after planting. $\mathrm{P}_{2} \mathrm{O}_{5}$ Application at rate of 50,45 and $40 \mathrm{~kg} / \mathrm{ha}$ recorded the highest and comparably similar height. Application of $\mathrm{P}_{2} \mathrm{O}_{5}$ at rate of $00 \mathrm{~kg} / \mathrm{ha}$ recorded the least height at 6 WAP. At the ninth week after planting, there was significant difference $(P=0.001)$ in plant height between the different rates of phosphorus application. Application of $\mathrm{P}_{2} \mathrm{O}_{5}$ at rate of 50 $\mathrm{kg} / \mathrm{ha}$ recorded the highest height followed by $\mathrm{P}_{2} \mathrm{O}_{5}$ application at rate of 45 and $40 \mathrm{~kg} / \mathrm{ha}$. The application of $\mathrm{P}_{2} \mathrm{O}_{5}$ at rate of $00 \mathrm{~kg} / \mathrm{ha}$ recorded the least height at the ninth week after planting.

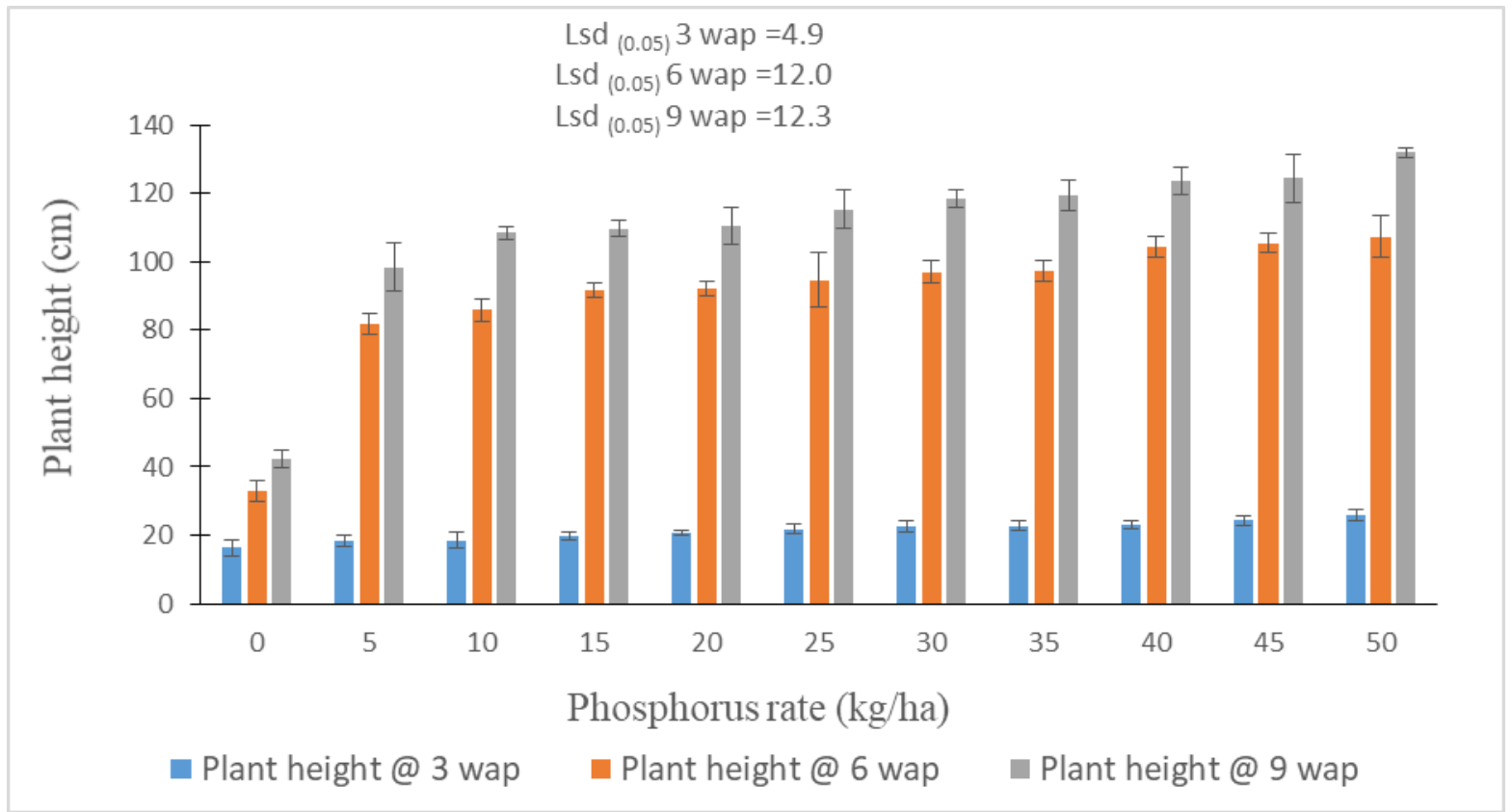

Figure 1: Impact of $\mathrm{P}_{2} \mathrm{O}_{5}$ calibration rate on plant height of maize at three (3) weeks after planting (wap), 6 weeks after planting and 9 weeks after planting in the guinea savannah zone of Ghana. Error bars represent standard error of means (SEM). 


\section{Leaf area index}

The application of different rates of phosphorus significantly $(P=0.001)$ influenced leaf area index at sixth week after planting with $50 \mathrm{~kg} / \mathrm{ha}$ of $\mathrm{P}_{2} \mathrm{O}_{5}$ recording the highest followed by $25 \mathrm{~kg}$ /ha of $\mathrm{P}$ while $00 \mathrm{~kg} / \mathrm{ha} \mathrm{P}$ recorded the least (Figure 2). Moreover, leaf area index at ninth week after planting was also significantly $(P=0.05)$ affected by the application of different rates of $\mathrm{P}_{2} \mathrm{O}_{5}$. However, at the 9 WAP, treatments that received $\mathrm{P}_{2} \mathrm{O}_{5}$ fertilization did not differ statistically in leaf area index (Figure 3). In contrast, $\mathrm{P}_{2} \mathrm{O}_{5}$ fertilized treatments had higher leaf area indices than treatments that did not receive $\mathrm{P}_{2} \mathrm{O}_{5}$ fertilization (Figure 3 ).

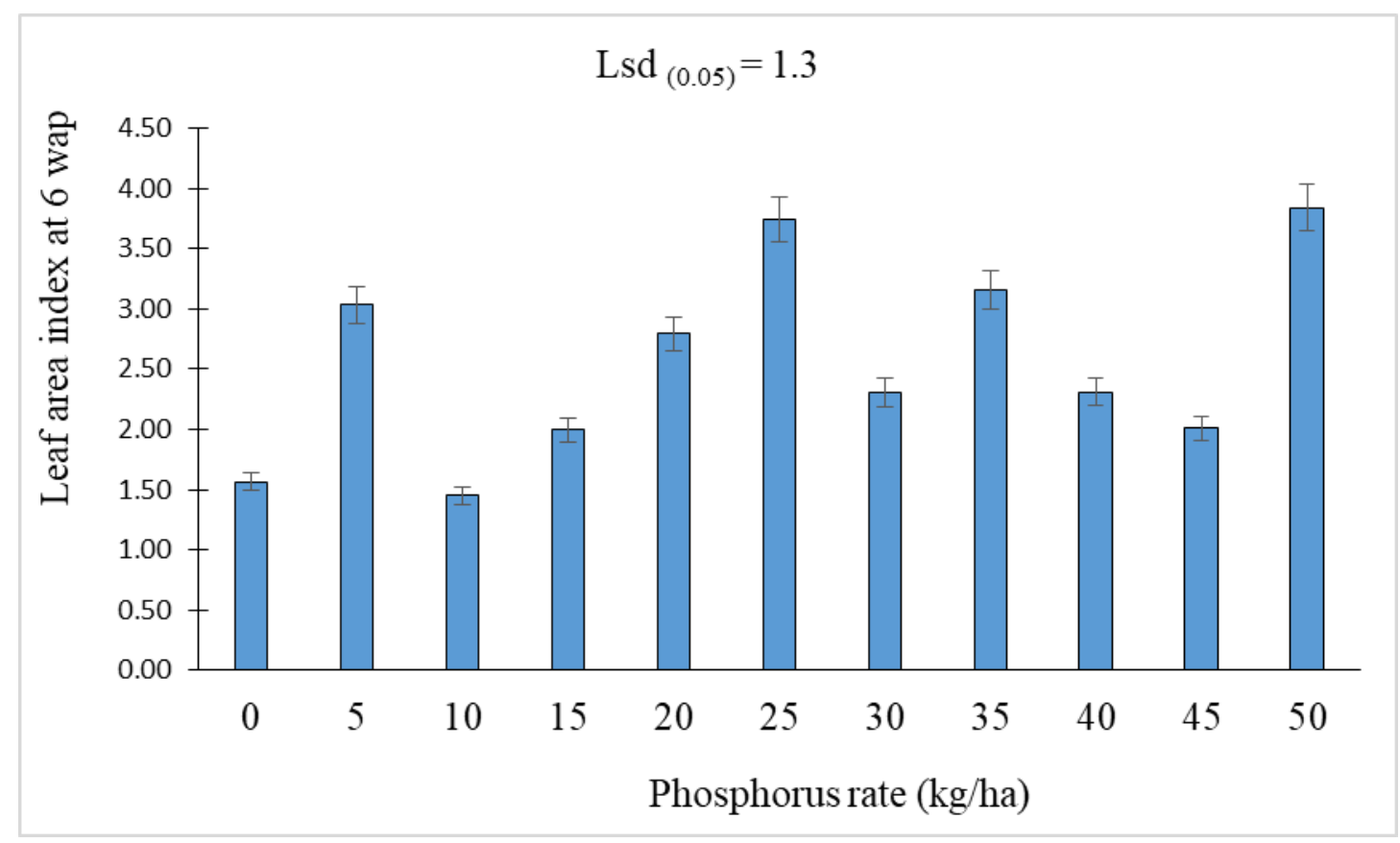

Figure 2: Impact of $\mathrm{P}_{2} \mathrm{O}_{5}$ calibration rate on leaf area index of maize at six (6) weeks after planting (wap) in the guinea savannah zone of Ghana. Error bars represent standard error of means (SEM). 


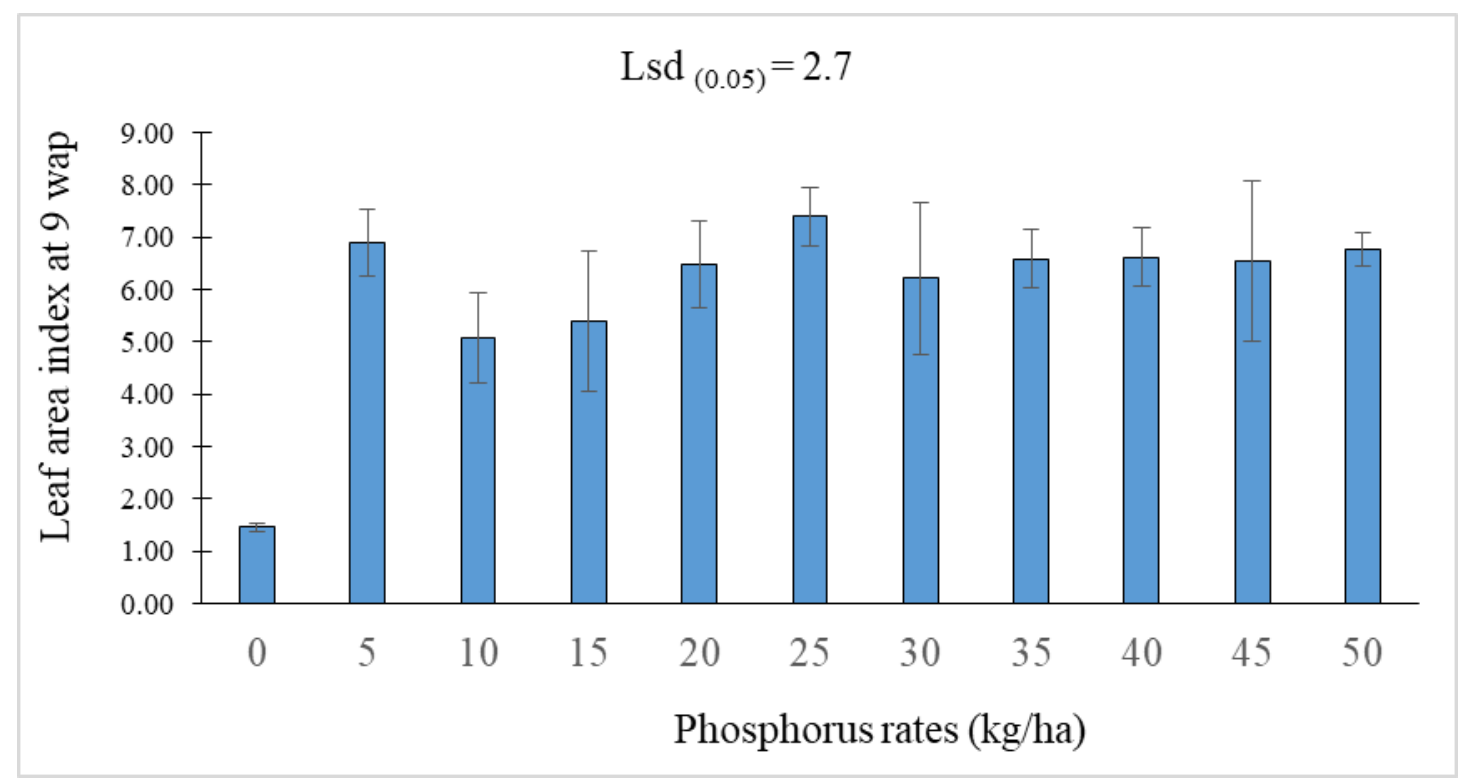

Figure 3: Impact of $\mathrm{P}_{2} \mathrm{O}_{5}$ calibration rate on leaf area index of maize at nine (9) weeks after planting (wap) in the guinea savannah zone of Ghana. Error bars represent standard error of means (SEM).

\section{Days to flowering}

Days to flowering was significantly affected $(P=0.05)$ by the rates of $\mathrm{P}_{2} \mathrm{O}_{5}$. The $50 \mathrm{~kg} / \mathrm{ha}$ rate of $\mathrm{P}_{2} \mathrm{O}_{5}$ recorded the least days to flower, which did not differ significantly from application at 25 and $20 \mathrm{~kg} / \mathrm{ha}$ (Figure 4). Application at $0 \mathrm{~kg} / \mathrm{ha}, 5 \mathrm{~kg} / \mathrm{ha}, 10 \mathrm{~kg} / \mathrm{ha}$ and $15 \mathrm{~kg} / \mathrm{ha}$ recorded the highest days to flower which were statistically comparable (Figure 4).

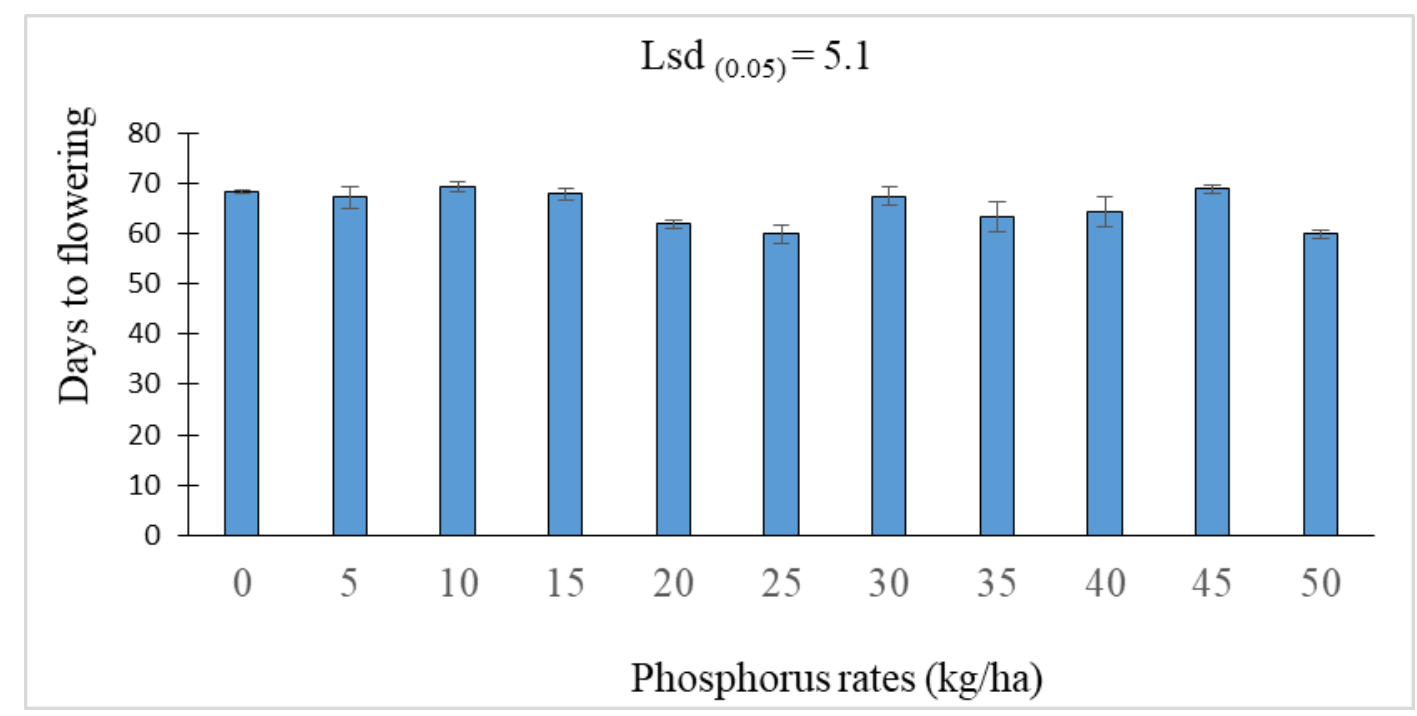

Figure 4: Impact of $\mathrm{P}_{2} \mathrm{O}_{5}$ calibration rate on days to $50 \%$ flowering of maize cultivated in the guinea savannah zone of Ghana. Error bars represent standard error of means (SEM). 


\section{Cob weight}

Cob weight was highly significantly affected $(P=0.001)$ by the application of different rates of phosphorus. Treatments that received $\mathrm{P}_{2} \mathrm{O}_{5}$ fertilization had higher cob weight than those that did not receive $\mathrm{P}_{2} \mathrm{O}_{5}$ fertilization (Figure 5). Within treatments that received phosphorus fertilization, cob weights were statistically comparable.

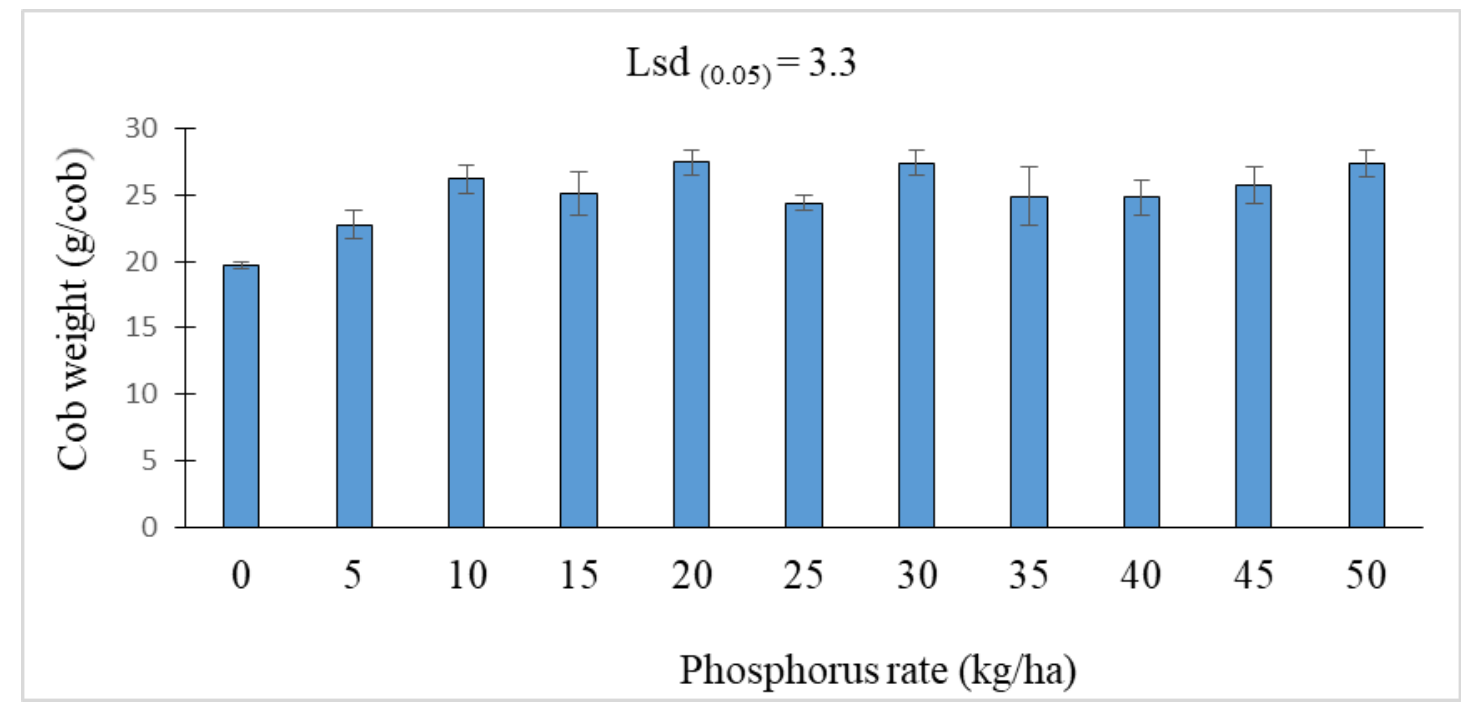

Figure 5: Impact of $\mathrm{P}_{2} \mathrm{O}_{5}$ calibration rate on cob weight of maize cultivated in the guinea savannah zone of Ghana. Error bars represent standard error of means (SEM).

\section{Cob length}

Cob length of maize varied significantly with rate of $\mathrm{P}_{2} \mathrm{O}_{5}$ application $(P=0.05)$. Application of $\mathrm{P}_{2} \mathrm{O}_{5}$ at rate of $35 \mathrm{~kg} / \mathrm{ha}$ resulted in the longest cob length of $14.9 \mathrm{~cm}$ (Figure 6). The cob length at rate of $35 \mathrm{~kg} / \mathrm{ha}$ were statistically same as cob length of $\mathrm{P}_{2} \mathrm{O}_{5}$ at rates between 15 and $50 \mathrm{~kg} / \mathrm{ha}$. The cob length at the higher rate of $35 \mathrm{~kg} / \mathrm{ha}$, however, differed significantly from cob length obtained at 0,5 , and $10 \mathrm{~kg} / \mathrm{ha}$ of $\mathrm{P}_{2} \mathrm{O}_{5}$.

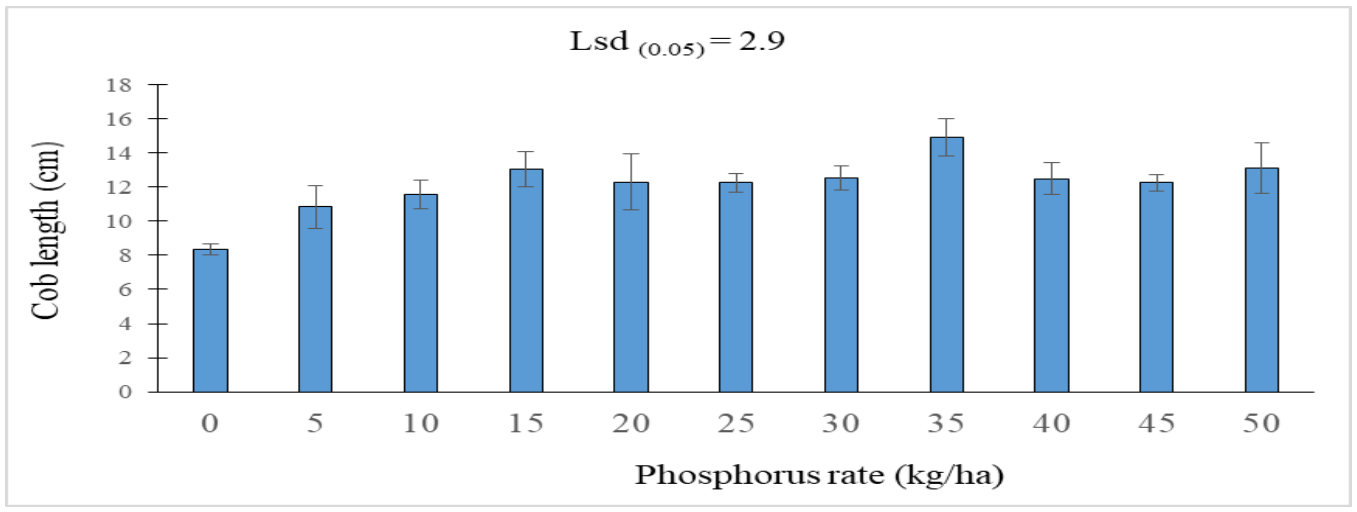

Figure 6: Impact of $\mathrm{P}_{2} \mathrm{O}_{5}$ calibration rate on cob length of maize cultivated in the guinea savannah zone of Ghana. Error bars represent standard error of means (SEM). 


\section{Weight of 100 seeds}

The weight of hundred seeds was significantly affected by the application of different rates of phosphorus. There was a general increase in hundred seeds weight with increasing rates of $\mathrm{P}_{2} \mathrm{O}_{5}$ application (Figure 7). Application of $\mathrm{P}_{2} \mathrm{O}_{5}$ at rate of $45 \mathrm{~kg} / \mathrm{ha}$ recorded the highest 100 seeds weight of $23.5 \mathrm{~g}$ followed by $50 \mathrm{~kg} / \mathrm{ha}(23.4 \mathrm{~g})$ respectively. The lowest 100 seeds weight of 14.8 $\mathrm{g}$ was recorded at $\mathrm{P}_{2} \mathrm{O}_{5}$ rate of $00 \mathrm{~kg} / \mathrm{ha}$ (Figure 7).

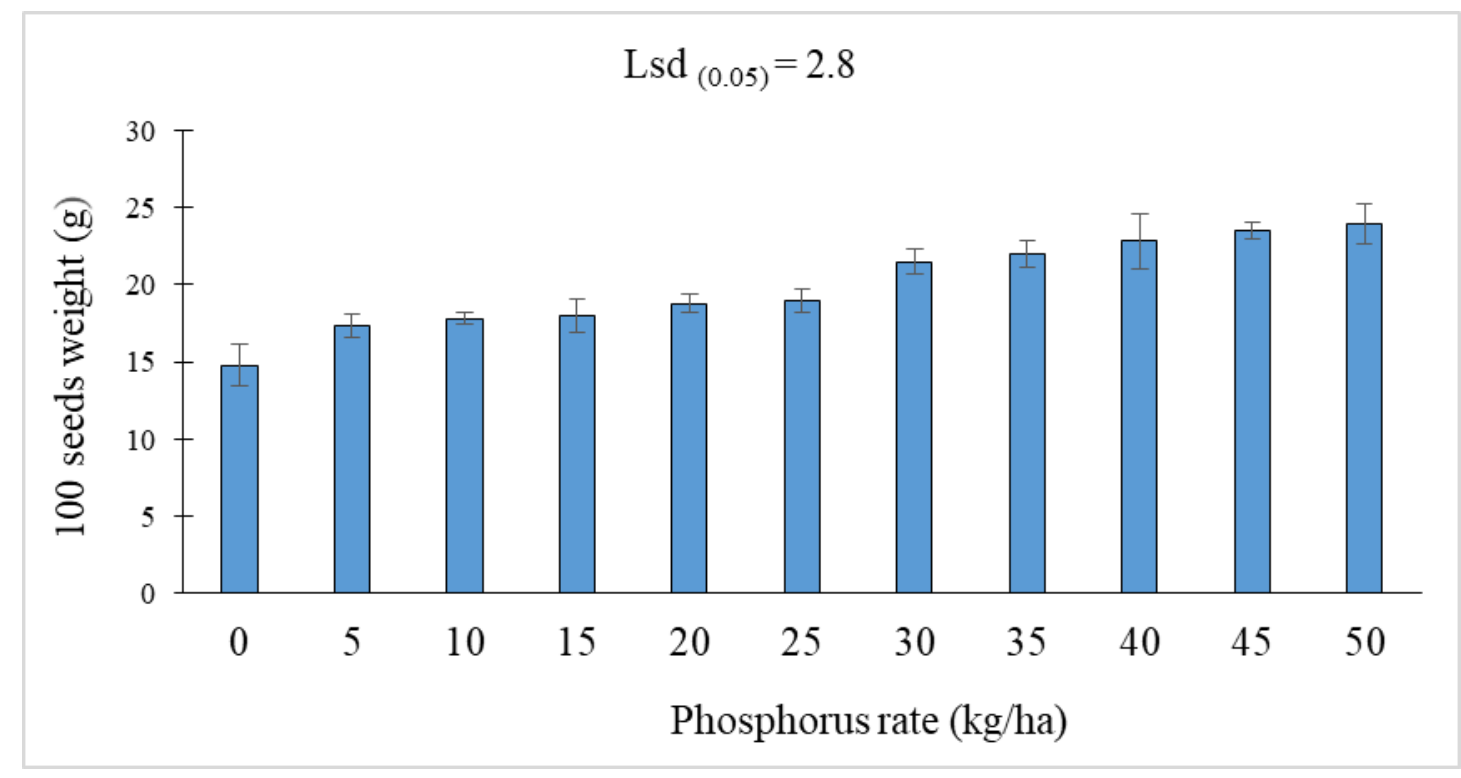

Figure 7: Impact of $\mathrm{P}_{2} \mathrm{O}_{5}$ calibration rate on 100 seeds weight of maize cultivated in the guinea savannah zone of Ghana. Error bars represent standard error of means (SEM).

\section{Straw weight}

Straw weight was highly significantly affected by the rates of $\mathrm{P}_{2} \mathrm{O}_{5}$ application. There was a general increase in straw weight with increasing rates of $\mathrm{P}_{2} \mathrm{O}_{5}$ application (Figure 8). Application of $\mathrm{P}_{2} \mathrm{O}_{5}$ at rate of $50 \mathrm{~kg} / \mathrm{ha}$ recorded the highest straw weight of $9.3 \mathrm{t} / \mathrm{ha}$ followed by $45 \mathrm{~kg} / \mathrm{ha}$ and $40 \mathrm{~kg} / \mathrm{ha}$ with 7.9 and $7.3 \mathrm{t} / \mathrm{ha}$ respectively, while $00 \mathrm{~kg} / \mathrm{ha}$ recorded the minimum straw weight (Figure 8). 


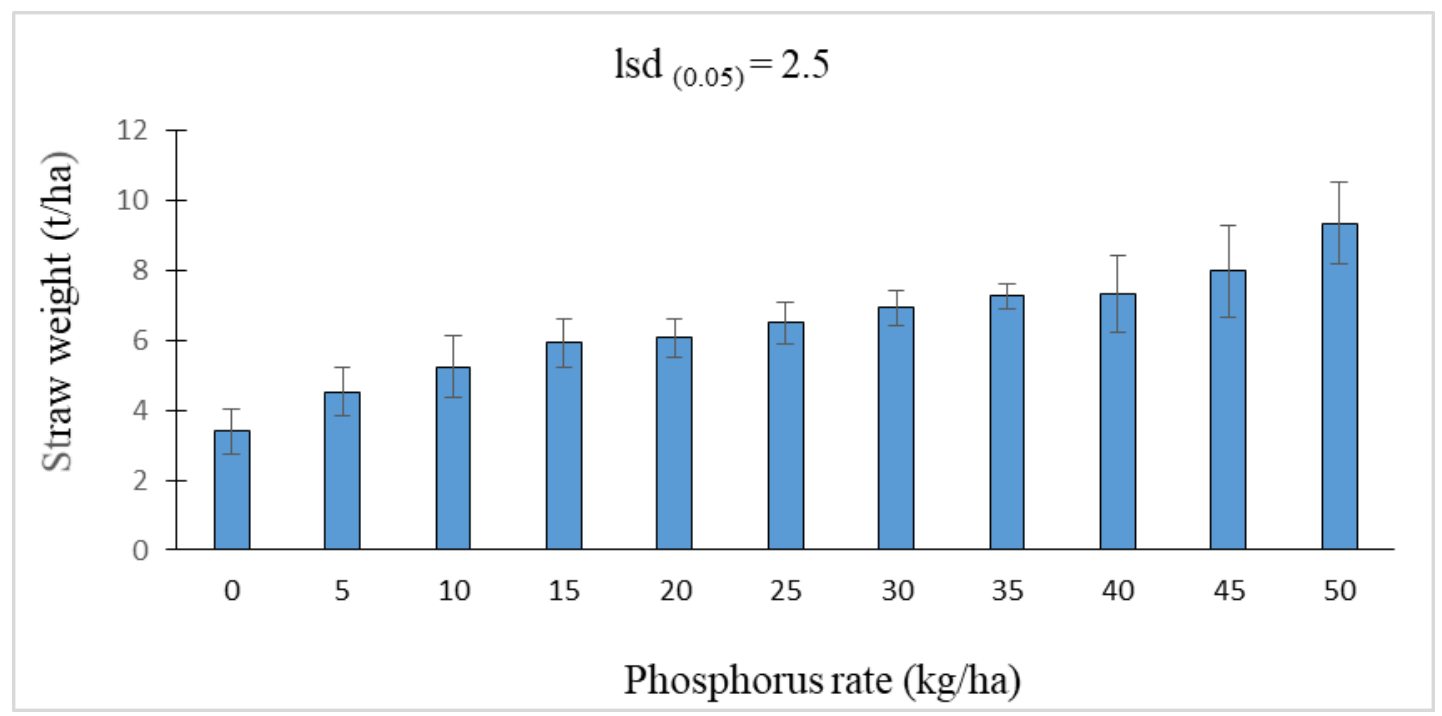

Figure 8: Impact of $\mathrm{P}_{2} \mathrm{O}_{5}$ calibration rate on straw weight of maize cultivated in the guinea savannah zone of Ghana. Error bars represent standard error of means (SEM)

\section{Grain yield}

Grain yield was highly significantly affected $(P=0.05)$ by phosphorus application at different rates. There was a general increase in grain yield with increasing rates of $\mathrm{P}_{2} \mathrm{O}_{5}$ application (Figure 9). From $35 \mathrm{~kg} / \mathrm{ha}$ to $50 \mathrm{~kg} / \mathrm{ha}$ of $\mathrm{P}_{2} \mathrm{O}_{5}$, grain yield was comparably similar. Generally, the yield obtained at $45 \mathrm{~kg} / \mathrm{ha}$ was similar to that obtained at $50 \mathrm{~kg} / \mathrm{ha}$ (3.09 t/ha). Phosphorus application at rate of $00 \mathrm{~kg} / \mathrm{ha}$ resulted in the lowest yield of $0.75 \mathrm{t} / \mathrm{ha}$ (Figure 9).

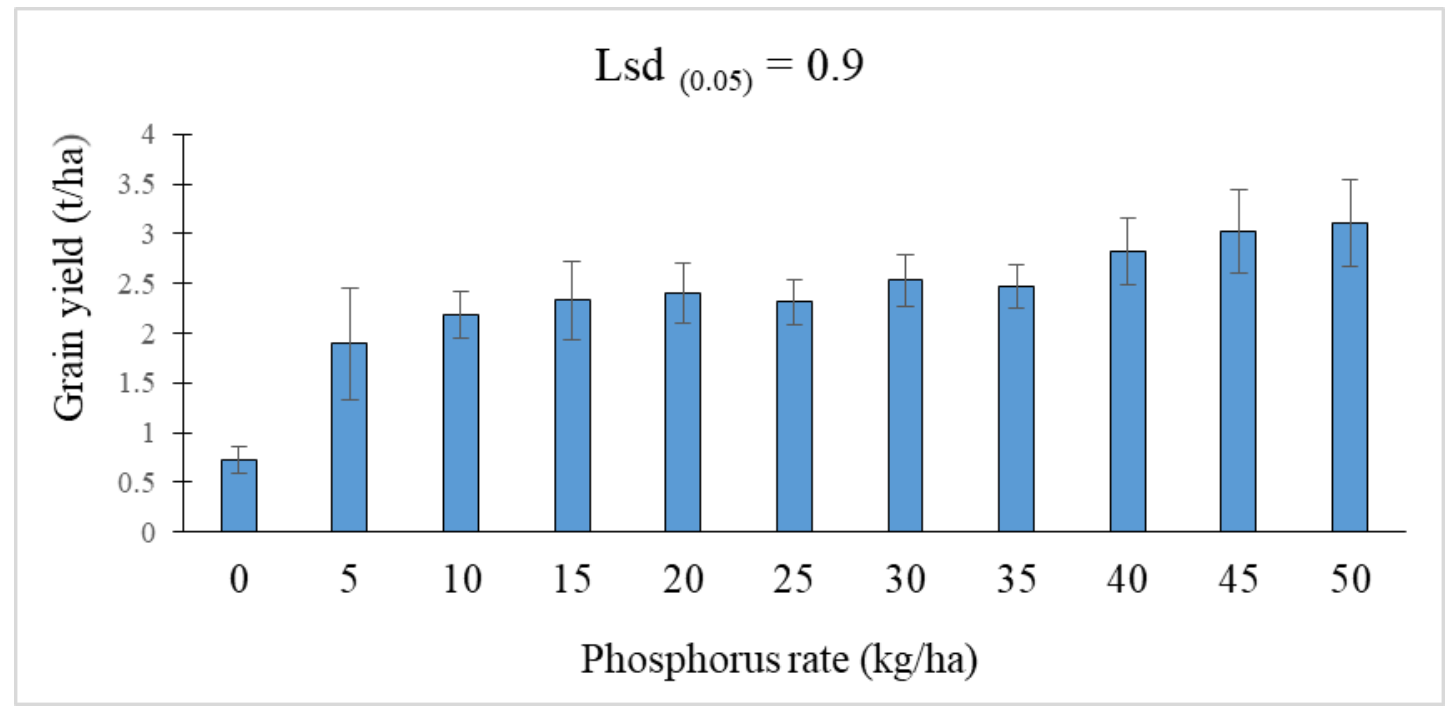

Figure 9: Impact of $\mathrm{P}_{2} \mathrm{O}_{5}$ calibration rate on grain yield of maize cultivated in the guinea savannah zone of Ghana. Error bars represent standard error of means (SEM). 
Vol. 06, No. 03; 2021

ISSN: $2456-8643$

\section{DISCUSSION}

The observed increases in plant height with increasing phosphorus fertilization rate (Figure 1) is in agreement with results of the study by $[34,35,36]$ who indicated that plant height of maize increased with increase in $\mathrm{P}_{2} \mathrm{O}_{5}$ application rate. The increase in plant height at higher rate of fertilization could be attributed to higher capacity to supply the P nutrient as needed for growth, resulting in vigorous vegetative growth which reflected in the significant increases in plant height. The maximum height of $131.9 \mathrm{~cm}$ that was recorded by $50 \mathrm{~kg} / \mathrm{ha}$ of $\mathrm{P}_{2} \mathrm{O}_{5}$ and minimum height of $42.1 \mathrm{~cm}$ that was recorded by $00 \mathrm{~kg} / \mathrm{ha} \mathrm{P}$ (Figure 1) is in agreement with the findings of [36] who reported that treatments with higher rate of phosphorus achieved higher plant height as compared with those with no phosphorus application. According to findings from studies by [37, 38], adequate amounts of phosphorus is necessary for early maturity, root and shoot development, rapid growth and also improves the quality of vegetative growth.

The observed significant effect of phosphorus fertilizer rate on leaf area index (Figure 2) is in agreement with findings of [39] who noted that application of $\mathrm{N}$ and $\mathrm{P}$ fertilizer significantly influenced leaf area index and dry biomass of corn. The significant increase in leaf area index at higher rates of $\mathrm{P}$ application could be due to enhanced $\mathrm{P}$ availability to the plant. Enhanced availability has positive influence on the vegetative morphology of the maize plant which leads to increases in leaf area index [40,41]. According to results of studies by [42, 43, 44] leaf area in maize increases with increasing rates of $\mathrm{P}$ application than under no fertilization.

The difference observed among the $\mathrm{P}_{2} \mathrm{O}_{5}$ application rates on cob weight and cob length (Figure 5 and Figure 6) is in agreement with results by [45, 46, 47, 48] who reported that growth parameters and yield of maize viz., plant height, cob length, cob weight, number of grain and grain yield were significantly influenced by phosphorus application and its levels. The increase in cob weight and cob length could be ascribed to enhanced P availability for the production of assimilates that were transformed to these yield components [49]. Similar results have been reported by [50]. Studies by [51, 52] reported that cob length, cob diameter, 100-grain weight and grain yield, significantly $(P=0.05)$ increased with increasing levels of $\mathrm{P}$ application.

Data regarding straw weight revealed that different levels of phosphorus had a significant $(P=$ 0.001) influence on straw weight and is in agreement with studies by [53] who reported that application of $\mathrm{P}_{2} \mathrm{O}_{5}$ fertilizer at increasing rates of $\mathrm{N}$ and $\mathrm{K}$ significantly improved straw yield and grain yield. Highest straw weight of $9.3 \mathrm{t} / \mathrm{ha}$ was attained in plots with phosphorus applied at rate of $50 \mathrm{t} / \mathrm{ha}$ as compared with the plots without phosphorus application (control plot) where straw weight was lowest of $3.3 \mathrm{t} /$ ha (Figure 8). The significant effect of $\mathrm{P}$ fertilization could be attributed to the test crop's root growth and development which was enhanced by the application of phosphorus and which resulted in increased straw weight due to photosynthesis and other biological functions. Similar reasoning are provided by $[54,55,56]$. According to report by $[57$, 58] dry matter production by crop plants is subject to nutrient availability, uptake and photosynthetic capacity of the vegetative parts of the plants. Generally, there was increase in straw weight with increase in phosphorus levels which was in agreement with findings of [59]. The authors reported that straw yield significantly increase with increasing levels of phosphorus application. 
In estimating grain yield, the weight of hundred seeds is considered as one of the best yield components which help in crop grain estimation. As with the results of this study, weight of seeds differed statistically in results of studies by [60] who observed significant effect on 1000 seed weight as affected by different P levels. The highest weight of hundred seeds of $23.49 \mathrm{~g}$ was recorded in the plot with phosphorus applied at rate of $50 \mathrm{~kg} / \mathrm{ha}$ while the minimum weight of hundred seeds of $14.8 \mathrm{~g}$ was recorded in treatments without phosphorus application (Figure 7). The observation in this study confirms a report by [61] who recorded highest thousand seed weight in treatments that received maximum rates of application of phosphorus and least thousand seed weight in treatments that received zero application of phosphorus. Phosphorus level, applied at $50 \mathrm{~kg} / \mathrm{ha}$ was most yield-enhancing. Similar results of impact of phosphorus rate on hundred seed weight has been reported by $[62,63]$.

As with most parameters, grain yield was statistically affected by the rates of $\mathrm{P}$ fertilization as also observed by [60]. The resulting higher yields under higher P fertilization (Figure 9) is in line with observations by [64] who reported that higher grain yield was obtained in treatments with higher application rates of phosphorus fertilizer and least yield in those with zero application rates of phosphorus fertilizer. Application of phosphorus at higher rates resulted in longer cobs, and more weight of cob which reflected in greater grain yield as compared to the control plots [65]. The increase in yield at higher rates of fertilization is also attributed to desirable increases in production and dry mass accumulation per unit increase in P content. Such increases in grain yield with increasing $\mathrm{P}$ application has also been reported by [66, 67, 68]. Research by $[54,69]$ reported that optimum supply of $\mathrm{P}$ is associated with increased root growth due to which the plants are able to explore more soil environment and moisture and thereby facilitate nutrient uptake, crop growth and development.

The observation on response of maize to incremental rates of $\mathrm{P}$ fertilization is an essential knowledge which paves way for further development of site specific fertilizations for the nutrient-poor Lixisols. This knowledge is the first required step in a multi-level procedure for development of comprehensive crop and soil data for site-specific nutrient formulation. The next step is to develop the tool that can predict soil $\mathrm{P}$ fertility status and the required $\mathrm{P}_{2} \mathrm{O}_{5}$ top-up that is needed for optimum maize production. The developed tool will aid scientists and researchers to predict site-specific fertilization that are based solely on maize nutrient requirement and the results obtained from laboratory analyses of soil $\mathrm{P}$. This will eliminate the current approach of using a one-suite recommended rate of $45 \mathrm{~kg} / \mathrm{ha}$ of nitrogen for all sites irrespective of the inherent differences and variations in soil nutrients at different locations.

\section{CONCLUSION AND RECOMMENDATION}

Growth and yield parameters of maize increased with increasing rates of $\mathrm{P}_{2} \mathrm{O}_{5}$ fertilization in the $\mathrm{P}$ depleted Lixisols of northern Ghana. Higher leaf area index $\left(3.84 \mathrm{~m}^{2} / \mathrm{m}^{2}\right), 100$ seed weight $(23.49 \mathrm{~g})$, straw weight $(9.3 \mathrm{t} / \mathrm{ha})$ and grain yield $(3.09 \mathrm{t} / \mathrm{ha})$ were obtained by higher rate of 50 $\mathrm{kg} / \mathrm{ha} \mathrm{P}_{2} \mathrm{O}_{5}$, but in most cases growth and yield at this rate was statistically similar with those obtained by $\mathrm{P}_{2} \mathrm{O}_{5}$ application rate of $45 \mathrm{~kg} / \mathrm{ha}$; indicating that a rate of $45 \mathrm{~kg} / \mathrm{ha}$ is generally suitable for the P-depleted Lixisols of northern Ghana. The study confirms that growth and yield 
of maize is affected by phosphorus fertilization and provides crop response data that are required as knowledge base for development of site-specific $\mathrm{P}_{2} \mathrm{O}_{5}$ fertilization regimes.

\section{REFERENCE}

[1] Bouis, H. E., and Welch, R. M. (2010). Biofortification - a sustainable agricultural strategy for reducing micronutrient malnutrition in the global south. Crop Science, 50(1): S-20.

[2] Olaniyan, A. B. (2015). Maize: Panacea for hunger in Nigeria. African Journal of Plant Science, 9(3): 155-174.

[3] Yussif, M. M. (2019). Social networks and integrated soil fertility management adoption: effects on maize yields and food security of farmers in Northern Region (Doctoral dissertation, Department of Economics, University for Development Studies).

[4] Ministry of Food and Agriculture (MoFA) (2015). A complete curriculum and guide to maize production in Ghana.

[5] Ayinla, O. A. (2007). Analysis of feeds and fertilizers for sustainable aquaculture development in Nigeria. FAO Fisheries Technical Paper, 497: 453.

[6] Kotu, B., and Admassie, A. (2015). Potential impact of improved varieties on poverty reduction: a case study of selected cereal crops in two districts of Ethiopia, 1008: 201680308.

[7] Anyanwu, C. N., Ibeto, C. N., Ezeoha, S. L., and Ogbuagu, N. J. (2015). Sustainability of cassava (Manihot esculenta Crantz) as industrial feedstock, energy and food crop in Nigeria. Renewable energy, 81: 745-752.

[8] Kenea, W. B., Reidsma, P., Descheemaeker, K., Rurinda, J., Balemi, T., \& van Ittersum, M. K. (2021). Variability in yield responses, physiological use efficiencies and recovery fractions of fertilizer use in maize in Ethiopia. European Journal of Agronomy, 124: 126228.

[9] Vesterager, J. M., Nielsen, N. E., and Høgh-Jensen, H. (2007). Nitrogen budgets in crop sequences with or without phosphorus-fertilised cowpea in the maize-based cropping systems of semi-arid eastern Africa. African Journal of Agricultural Research, 2(6): 261-268.

[10] Gou, X., Cai, Y., Wang, C., Li, B., Zhang, Y., Tang, X., ... \& Cai, Z. (2020). Effects of different long-term cropping systems on phosphorus adsorption and desorption characteristics in red soils. Journal of Soils and Sediments, 20(3): 1371-1382.

[11] Yang, J. C., Zhang, H., and Zhang, J. H. (2012). Root morphology and physiology in relation to the yield formation of rice. Journal of Integrative Agriculture, 11(6): 920-926.

[12] White, P. J., and Veneklaas, E. J. (2012). Nature and nurture: the importance of seed phosphorus content. Plant and soil, 357(1-2): 1-8.

[13] Walters, R. G., Ibrahim, D. G., Horton, P., and Kruger, N. J. (2004). A mutant of Arabidopsis lacking the triose-phosphate/phosphate translocator reveals metabolic regulation of starch breakdown in the light. Plant Physiology, 135(2): 891-906.

[14] Vos, J. P. E. L., Van Der Putten, P. E. L., and Birch, C. J. (2005). Effect of nitrogen supply on leaf appearance, leaf growth, leaf nitrogen economy and photosynthetic capacity in maize (Zea mays L.). Field Crops Research, 93(1): 64-73.

[15] Simpson, R. J., Oberson, A., Culvenor, R. A., Ryan, M. H., Veneklaas, E. J., Lambers, H., and Smith, S. E. (2011). Strategies and agronomic interventions to improve the phosphorus-use efficiency of farming systems. Plant and Soil, 349(1-2): 89-120. 
[16] Tabbasum, S., Akhtar, M., Sarwar, N., Tipu, M. I., Ikram, W., Ashraf, A., ... \& Khan, M. R. (2021). Relative Effectiveness of Phosphorus and Potassium Along with Compost and Organic Acids on Maize Crop Grown in Calcareous Soil: a Multivariate Analysis. Journal of Soil Science and Plant Nutrition, 21(1): 437-449.

[17] Timler, C., Alvarez, S., DeClerck, F., Remans, R., Raneri, J., Carmona, N. E., ... \& Groot, J. C. (2020). Exploring solution spaces for nutrition-sensitive agriculture in Kenya and Vietnam. Agricultural Systems, 180: 102774.

[18] Taveira, C. J., Farrell, R. E., Wagner-Riddle, C., Machado, P. V. F., Deen, B., \& Congreves, K. A. (2020). Tracing crop residue $\mathrm{N}$ into subsequent crops: Insight from longterm crop rotations that vary in diversity. Field Crops Research, 255: 107904.

[19] McLaughlin, M. J., McBeath, T. M., Smernik, R., Stacey, S. P., Ajiboye, B., and Guppy, C. (2011). The chemical nature of $P$ accumulation in agricultural soils-implications for fertiliser management and design: an Australian perspective. Plant and Soil, 349(1-2): 69-87.

[20] Kisinyo, P., \& Opala, P. (2020). Depletion of phosphate rock reserves and world food crisis: Reality or hoax, African Journal of Agricultural Research, Vol. 16(9): 1223-1227 http://www.academicjournals.org/AJAR, DOI: 10.5897/AJAR2020.14892

[21] Chen, Q. S., Sun, S. Y., Liu, Y. K., Qi, C. C., Zhou, H. B., \& Zhang, Q. L. (2021). Experimental and numerical study on immobilization and leaching characteristics of fluoride from phosphogypsum based cemented paste backfill. International Journal of Minerals, Metallury and Materials. https://doi.org/10.1007/s12613-021-2274-6

[22] Unuofin, J. O. (2020). Garbage in garbage out: the contribution of our industrial advancement to wastewater degeneration. Environmental Science and Pollution Research, 27(18): 22319-22335.

[23] Mäkelä, P. S., Wasonga, D. O., Solano Hernandez, A., \& Santanen, A. (2020). Seedling growth and phosphorus uptake in response to different phosphorus sources. Agronomy, 10(8): 1089.

[24] Appiah, E. A., Kugbe, J. X., \& Rufai, A. M. (2020). Maize Growth and Yield Response to Incremental Rates of Nitrogen in N-Depleted Lixisols in Northern Ghana. International Journal of Plant \& Soil Science, 16-30.

[25] Berkowitz, J. F., Schlea, D. A., VanZomeren, C. M., \& Boles, C. M. (2020). Coupling watershed modeling, public engagement, and soil analysis improves decision making for targeting P retention wetland locations. Journal of Great Lakes Research, 46(5): 1331-1339.

[26] Ampofo, S., Ampadu, B., DoutI, N. B., \& Kusibu, M. M. (2020). Modeling soil water balance of an agricultural watershed in the Guinea Savannah Agro-ecological Zone; a case of the Tono irrigation dam watershed. Ghana Journal of Science, Technology and Development, 7(1): 69-81.

[27] Abunyewa, A. A., and Karbo, K. N. (2005). Improved fallow with pigeon pea for soil fertility improvement and to increase maize production in a smallholder crop-livestock farming system in the sub-humid zone of Ghana. Land degradation \& development, 16(5): 447-454.

[28] SARI, (1996), Savannah Agricultural Research Institute. Annual report

[29] Nelson, D.W. and L.E. Somers, (1992). Total carbon, total organic carbon and organic matter. pp: 539-580. In: A.L. Miller et al., (ed). Methods of soil analysis, Part 2, 2 Edition, Agronomy Monograph, 27, ASA, nd Madison, WI. 
Vol. 06, No. 03; 2021

ISSN: $2456-8643$

[30] Bremner, J. M. (1965). Total nitrogen. Methods of Soil Analysis: Part 2 Chemical and Microbiological Properties, 9: 1149-1178.

[31] Bray, R. H., and Kurtz, L. T. (1945). Determination of total, organic, and available forms of phosphorus in soils. Soil science, 59(1): 39-46.

[32] Dwyer, L. M., and Stewart, D. W. (1986). Leaf Area Development in Field-Grown Maize Agronomy Journal, 78(2): 334-343.

[33] Goswani, B. (2011). Remediation for rice cultivation on soil affected by coal mining in Jaintia Hills, Meghalaya (Doctoral dissertation, North-Eastern University).

[34] Eltelib, H. A., Hamad, M. A., and Ali, E. E. (2006). The effect of nitrogen and phosphorus fertilization on growth, yield and quality of forage maize (Zea mays L.). Journal of. Agronomy, 5(3): 515-518.

[35] Asghar, A., Ali, A., Syed, W. H., Asif, M., Khaliq, T., and Abid, A. A. (2010). Growth and yield of maize (Zea mays L.) cultivars affected by NPK application in different proportion. Pakistan journal of Science, 62(4): 211-216.

[36] Masood, T., Gul, R., Munsif, F., Jalal, F., Hussain, Z., Noreen, N., Khan, H., and Nasiruddin, K. H. (2011). Effect of Different Phosphorous Level on the Yield and Yield Component of Maize. Sarhad Journal of Agriculture, 27: 167-170.

[37] Ball, D. M., Collins, M., Lacefield, G. D., Martin, N. P., Mertens, D. A., Olson, K. E., and Wolf, M. W. (2001). Understanding forage quality. American Farm Bureau Federation Publication, 1(01). Park Ridge, IL.

[38] Krishnan, P., Ramakrishnan, B., Reddy, K. R., and Reddy, V. R. (2011). Hightemperature effects on rice growth, yield, and grain quality. In Advances in agronomy, 111: 87-206.

[39] Besufekad, Y., Beri, S., Adugnaw, T., and Beyene, K. (2018). Antibacterial activity of Ethiopian Lepidium sativum L. against pathogenic bacteria. Journal of Medicinal Plants Research, 12: 64-68.

[40] Namgay, T., Singh, B., and Singh, B. P. (2010). Influence of biochar application to soil on the availability of $\mathrm{As}, \mathrm{Cd}, \mathrm{Cu}, \mathrm{Pb}$, and $\mathrm{Zn}$ to maize (Zea mays L.). Soil Research, 48(7): 638-647.

[41] Teixeira, R. D. S., Ribeiro da Silva, I., Nogueira de Sousa, R., Márcio Mattiello, E., and Barros Soares, E. M. (2016). Organic acid coated-slow-release phosphorus fertilizers improve $\mathrm{P}$ availability and maize growth in a tropical soil. Journal of soil science and plant nutrition, 16(4): 1097-1112.

[42] Amanullah, M. K., Marwat, K. B., Shah, P., Maula, N., and Arifullah, S. (2009). Nitrogen levels and its time of application influence leaf area, height and biomass of maize planted at low and high density. Pakistan Journal of Botany, 41(2): 761-768.

[43] Onasanya, R. O., Aiyelari, O. P., Onasanya, A., Oikeh, S., Nwilene, F. E., and Oyelakin, O. O. (2009). Growth and yield response of maize (Zea mays L.) to different rates of nitrogen and phosphorus fertilizers in southern Nigeria. World Journal of Agricultural Sciences, 5(4): 400-407.

[44] Khalil, S., Hussain, Z., Tariq, M., and Rahman, H. (2010). Impact of planting density and P-fertilizer source on the growth analysis of maize. Pakistan Journal of Botany, 42(4): 2349-2357. 
[45] El-Kholy, M. A., El-Ashry, S., and Gomaa, A. M. (2005). Biofertilization of maize crop and its impact on yield and grains nutrient content under low rates of mineral fertilizers. Journal of Applied Sciences Research, 1(2): 117-121.

[46] Sampathkumar, T., Pandian, B. J., Rangaswamy, M. V., Manickasundaram, P., and Jeyakumar, P. (2013). Influence of deficit irrigation on growth, yield and yield parameters of cotton-maize cropping sequence. Agricultural water management, 130: 90-102.

[47] Mohsin, A. U., Ahmad, A. U. H., Farooq, M., and Ullah, S. (2014). Influence of zinc application through seed treatment and foliar spray on growth, productivity and grain quality of hybrid maize. Journal of Animal and Plant Sciences, 24(5): 1494-1503.

[48] Pal, B., Hirpara1, D.S., Vora, V.D., Vekaria, P.D., Sutaria, G.S., Akbari, K.N., and Verma, H.P. (2017). Effect of Nitrogen and Phosphorus on Yield and Yield Attributes of Maize in South Saurashtra, India. International Journal of Current Microbiology and Applied Sciences, 6 (3): 1945 - 1949.

[49] Lashkari, M., Madani, H., Ardakani, M. R., Golzardi, F., and Zargari, K. (2011). Effect of plant density on yield and yield components of different corn (Zea mays L.) hybrids. AmEuras Journal of Agriculture Environmental Science, 10(3): 450-457.

[50] Plénet, D., Mollier, A., and Pellerin, S. (2000). Growth analysis of maize field crops under phosphorus deficiency. II. Radiation use efficiency, biomass accumulation and yield components. Plant Soil, 224: 259-272.

[51] Olusegun, O. S. (2015). Nitrogen (N) and phosphorus (P) fertilizer application on maize (Zea mays L.) growth and yield at Ado-Ekiti, South-West, Nigeria. Journal of Experimental Agriculture International, 22-29.

[52] Greaves, G. E., and Wang, Y. M. (2017). Yield response, water productivity, and seasonal water production functions for maize under deficit irrigation water management in southern Taiwan. Plant Production Science, 20(4): 353-365.

[53] Saha, S., Saha, B., Murmu, S., Pati, S., and Roy, P. D. (2014). Grain yield and phosphorus uptake by wheat as influenced by long-term phosphorus fertilization. African. Journal of Agriculture Research, 9: 607-612.

[54] Fageria, N. K., and Moreira, A. (2011). The role of mineral nutrition on root growth of crop plants. In Advances in agronomy, 110: 251-331.

[55] Veneklaas, E. J., Lambers, H., Bragg, J., Finnegan, P. M., Lovelock, C. E., Plaxton, W. C., and Raven, J. A. (2012). Opportunities for improving phosphorus-use efficiency in crop plants. New Phytologist, 195(2): 306-320.

[56] Calvo, P., Nelson, L., and Kloepper, J. W. (2014). Agricultural uses of plant biostimulants. Plant and soil, 383(1-2): 3-41.

[57] Van Camp, W. (2005). Yield enhancement genes: seeds for growth. Current Opinion in Biotechnology, 16(2): 147-153.

[58] Boote, K. J., Jones, J. W., White, J. W., Asseng, S., and Lizaso, J. I. (2013). Putting mechanisms into crop production models. Plant, cell \& environment, 36(9): 1658-1672.

[59] Jiang, B., Jianlin, S. H. E. N., Minghong, S. U. N., Yajun, H. U., Jiang, W., Juan, W. A. N. G., ... \& Jinshui, W. U. (2021). Soil phosphorus availability and rice phosphorus uptake in paddy fields under various agronomic practices. Pedosphere, 31(1): 103-115. 
[60] Khan, F., Khan, S., Fahad, S., Faisal, S., Hussain, S., Ali, S., and Ali, A. (2014). Effect of different levels of nitrogen and phosphorus on the phenology and yield of maize varieties. American Journal of Plant Sciences, 5(17): 9-18.

[61] Allah, Y. A. (2021). THE PREDICTION OF THE COMBINATION EFFECT OF COMPOST, NITROGEN AND PHOSPHORUS FERTILIZERS ON SOME SOIL PROPERTIES AND PRODUCTIVITY OF WHEAT AND MAIZE YIELDS. Menoufia Journal of Soil Science, 6(3): 49-71.

[62] Arif, M., Ali, A., Umair, M., Munsif, F., Ali, K., Inamullah, M. S., and Ayub, G. (2012). Effect of biochar FYM and mineral nitrogen alone and in combination on yield and yield components of maize. Sarhad Journal of Agriculture, 28(2): 191-195.

[63] Hussain, N., Khan, A. Z., Akbar, H., and Akhtar, S. (2006). Growth factors and yield of maize as influenced by phosphorus and potash fertilization. Sarhad Journal of Agriculture, 22(4): 579-583.

[64] Khan, M. J., Muhammad, D., Fahad, S., Adnan, M., Wahid, F., Alamri, S.. \& Siddiqui, M. H. (2020). Phosphorus Nutrient Management through Synchronization of Application Methods and Rates in Wheat and Maize Crops. Plants, 9(10): 1389.

[65] Arif, M., Ali, A., Umair, M., Munsif, F., Ali, K., Inamullah, M. S., and Ayub, G. (2012). Effect of biochar FYM and mineral nitrogen alone and in combination on yield and yield components of maize. Sarhad Journal of Agriculture, 28(2): 191-195.

[66] Agegnehu, G., Bass, A. M., Nelson, P. N., and Bird, M. I. (2016). Benefits of biochar, compost and biochar-compost for soil quality, maize yield and greenhouse gas emissions in a tropical agricultural soil. Science of the Total Environment, 543: 295-306.

[67] Potarzycki, J., and Grzebisz, W. (2009). Effect of zinc foliar application on grain yield of maize and its yielding compone. Plant, Soil and Environment, 55(12): 519-527.

[68] Ahmad, M., Khan, M. J., and Muhammad, D. (2013). Response of maize to different phosphorus levels under calcareous soil conditions. Sarhad Journal of Agriculture, 29(1): 4348.

[69] Grant, C., Bittman, S., Montreal, M., Plenchette, C., and Morel, C. (2005). Soil and fertilizer phosphorus: Effects on plant $\mathrm{P}$ supply and mycorrhizal development. Canadian Journal of Plant Science, 85(1): 3-14. 